\title{
Myelin Repair Is Accelerated by Inactivating CXCR2 on Nonhematopoietic Cells
}

\author{
LiPing Liu, ${ }^{1}$ Lindsey Darnall, ${ }^{1}$ Taofang Hu, ${ }^{1}$ Karen Choi, ${ }^{1}$ Thomas E. Lane, ${ }^{2}$ and Richard M. Ransohoff ${ }^{1}$ \\ ${ }^{1}$ Neuroinflammation Research Centre, Department of Neuroscience, Lerner Research Institute, Cleveland Clinic, Cleveland, Ohio 44195, and ${ }^{2}$ Department \\ of Molecular Biology \& Biochemistry, University of California, Irvine, Irvine, California 92697
}

\begin{abstract}
Multiple sclerosis (MS) is an inflammatory demyelinating disease of the CNS and remyelination in MS ultimately fails. Although strategies to promote myelin repair are eagerly sought, mechanisms underlying remyelination in vivo have been elusive. CXCR2 is expressed on neutrophils and oligodendrocyte lineage cells in the CNS. CXCR2-positive neutrophils facilitate inflammatory demyelination in demyelination models such as experimental autoimmune encephalomyelitis (EAE) and cuprizone intoxication. Systemic injection of a small molecule CXCR2 antagonist at the onset of EAE decreased demyelinated lesions. These results left the cellular target of the CXCR2 antagonist uncertain and did not clarify whether CXCR2 blockade prevented demyelination or promoted remyelination. Here, we show that the actions of CXCR2 on nonhematopoietic cells unexpectedly delay myelin repair. Bone marrow chimeric mice $\left(\mathrm{Cxcr}^{+/-} \rightarrow \mathrm{CxCr}^{-I-}\right.$ and $\left.\mathrm{Cxcr2} 2^{+/-} \rightarrow \mathrm{Cxcr}^{+/+}\right)$were subjected to two distinct models of myelin injury. In all cases, myelin repair was more efficient in $\mathrm{Cxcr}^{+/-} \rightarrow \mathrm{Cxcr}^{-l-}$ animals. Oligodendrocyte progenitor cells (OPCs) in demyelinated lesions of $\mathrm{Cxcr} 2^{+/-} \rightarrow \mathrm{Cxcr}^{-1-}$ mice proliferated earlier and more vigorously than in tissues from $\mathrm{Cxcr} 2^{+/-} \rightarrow$ $\mathrm{Cxcr2}{ }^{+/+}$animals. In vitro demyelinated CNS slice cultures also showed better myelin repair when CXCR2 was blocked with neutralizing antibodies or was genetically deleted. Our results suggest that CXCR2 inactivation permits optimal spatiotemporal positioning of OPCs in demyelinating lesions to receive local proliferative and differentiating signals. Given that CXCR2 exerts dual functions that promote demyelination and decrease remyelination by actions toward hematopoietic cells and nonhematopoietic cells, respectively, our findings identify CXCR2 as a promising drug target for clinical demyelinating disorders.
\end{abstract}

\section{Introduction}

Multiple sclerosis (MS) is an inflammatory demyelinating disease of the CNS and remyelination in MS ultimately fails. In the CNS, oligodendrocyte progenitor cells (OPCs) carry out a complex, precisely timed program of migration, proliferation, and differentiation, followed by programmed cell death or myelination. Understanding remyelination is crucial for devising effective methods to prevent or reduce its failure in clinical demyelinating disorders.

Chemokines act through G-protein-coupled receptors to regulate cell movement, activation, proliferation, and differentiation. Receptors for CXC chemokines frequently act on both circulating leukocytes and parenchymal cells in solid organs, and orchestrate complex tissue modeling during development, angiogenesis, and neoplasia. CXCR2 is an ELR CXC chemokine receptor, also known as IL-8RB. It is expressed both on inflammatory myeloid cells such as neutrophils and on OPCs in the CNS. Peripheral expression of CXCR2 is important for recruitment of myeloid cells to sites of inflammation (Cacalano et al., 1994) and is implicated in cutaneous wound repair by promoting

Received March 8, 2010; revised April 20, 2010; accepted May 20, 2010.

This work was supported by National Multiple Sclerosis Society Grant RG 3580 (R.M.R.) and National Institutes of Health Grant NS32151 (R.M.R.). We thank W. Stallcup (Burnham Institute for Medical Research, La Jolla, CA) for generously providing antibody to PDGF receptor- $\alpha$ and Dr. Chris Nelson (Department of Neurosciences, Lerner Research Institute, (leveland Clinic, (leveland, $\mathrm{OH}$ ) for assistance with preparing this manuscript.

Correspondence should be addressed to Dr. Richard M. Ransohoff, Neuroinflammation Research Center, NC30, Cleveland Clinic, 9500 Euclid Avenue, Cleveland, 0hio 44195. E-mail: ransohr@ccf.org.

DOI:10.1523/JNEUROSCI.1238-10.2010

Copyright $\odot 2010$ the authors $\quad 0270-6474 / 10 / 309074-10 \$ 15.00 / 0$ neutrophil recruitment, keratinocyte proliferation, and angiogenesis (Devalaraja et al., 2000). Recently, our laboratory (Liu et al., 2010) as well as others (Carlson et al., 2008) identified the nonredundant role of peripheral expression of CXCR2 on neutrophils in the promotion of demyelination in the CNS in two animal models of demyelination, and expression of CXCR2 on OPCs was not involved in the demyelinating process (Liu et al., 2010).

CXCR2 expressed on OPCs in the developing rodent spinal cord governs both migratory arrest and (in the presence of PDGF) proliferative responses during development (Tsai et al., 2002). In postmortem tissues from MS cases, the CXCR2 ligand CXCL1 was detected in close proximity to oligodendrocytes on reactive astrocytes (Omari et al., 2006). Our laboratory found that CXCL1 and CXCL2 were upregulated on astrocytes near inflammatory foci in CNS tissues of mice with experimental autoimmune encephalomyelitis (EAE) (Glabinski et al., 1997). In a recent study, systemic treatment with a small molecular CXCR2 antagonist enhanced remyelination in EAE (Kerstetter et al., 2009). Furthermore, localized inhibition of CXCR2 with this antagonist enhanced remyelination in lysophosphatidylcholine (LPC)-induced demyelinating lesions. It remains uncertain which cells expressing CXCR2 contribute to remyelination after systemic or local inhibition of CXCR2. To distinguish whether peripheral or CNS CXCR2-positive cells impair remyelination, we evaluated CXCR2-deficient mice and CXCR2 bone marrow chimeric mice in two different demyelination/remyelination animal models. Inactivation of CXCR2 on nonhematopoietic cells accelerated myelin repair in both models. OPCs in the demyeli- 
nated lesions of CXCR2-deficient animals proliferated earlier and more vigorously than in tissues from exposed animals. Demyelinated CNS slice cultures also showed better myelin repair when CXCR2 was blocked or genetically deleted. Our data suggest that CXCR2 exerts functions on nonhematopoietic cells of the CNS that impair remyelination.

\section{Materials and Methods}

Mice. The generation of Cxcr2-deficient mice has been described previously (Cacalano et al., 1994). The animals used in these experiments had been backcrossed to SWR for at least nine generations. Then SWR background Cxcr2 heterozyogous mice were crossed with SJL mice, producing $\mathrm{F}_{1}$ SWXJ heterozygous mice which were then intercrossed with $\mathrm{F}_{1}$ Cxcr 2 heterozyogous mice, resulting in Cxcr 2 knock-out, heterozyogous, and wild-type mice. Alternatively, the animals had been backcrossed to C57BL/6J (B6) mice for 11 generations. All comparisons in the current studies were made between littermate mice, with cohorts of mice being matched for both gender and age. Cxcr2 genotype was established using PCR-based genomic DNA analyses as described previously (Tsai et al., 2002). SWR $\times$ SJL F $_{1}\left[\right.$ SWXJ $\left.\left(H-2^{q^{s}}\right)\right]$ mice haplotype was identified by flow cytometry (detail below) (data not shown). All experimental mice were at the age of $8-10$ weeks and were housed under pathogen-free conditions in the animal facility at the Cleveland Clinic. All protocols for animal research met the requirements of the Animal Research Committee of the Cleveland Clinic in compliance with the Public Health Service policy on humane care and use of laboratory animals.

Generation of Cxcr2 bone marrow chimeric mice and chimeric mice identification. For Cxcr2 bone marrow chimeric mice, 4- to 5-week-old female or male $\mathrm{Cxcr} 2^{+1+,-1-}$ mice were subjected to $900 \mathrm{rad}$ (using a ${ }^{137} \mathrm{Cs}$ source from a Shepherd irradiator model 81-14R; J. L. Shepherd \& Associates) of total body irradiation to eliminate most of the endogenous bone marrow-derived cells and stem cells. All irradiated mice were injected intravenously through the tail vein or with a retroorbital venous sinus injection with $1 \times 10^{7}$ bone marrow cells flushed and isolated from the femurs and tibias of donor heterozygous mice. Mice were maintained in gentamicin $(10 \mu \mathrm{g} / \mathrm{ml})$ (Invitrogen) via the drinking water for the first 4 weeks after transfer. Animals were allowed to recover for 6 weeks before additional experiments such as EAE induction and cuprizone feeding. After 6 weeks after transfer, all mice were bled, and the extent of engraftment was determined by staining of CXCR2 expression on peripheral leukocytes, particularly granulocytes by using CXCR antibody and Gr1 antibody to define the CXCR2 + granulocyte population by using flowcytometric analysis (Liu et al., 2010). Irradiation did not affect the integrity of the blood-brain barrier, confirmed by staining brain tissue sections for murine IgG to indicate serum protein leakage into the CNS 6 weeks after bone marrow transfer (data not shown), which is a sensitive indicator of blood-brain barrier integrity (Pedchenko and LeVine, 1999).

EAE induction in $\mathrm{Cxcr}^{+/+}, \mathrm{Cxcr} 2^{-/-}$mice, $\mathrm{Cxcr} 2^{+/+}$and $\mathrm{Cxcr} 2^{-/-}$ bone marrow radiation chimeric mice: peptides. Rat myelin oligodendroglial glycoprotein $\left(\mathrm{MOG}_{35-55}\right)$ and mouse proteolipid protein $\left(\mathrm{PLP}_{139-151}\right)$ peptides were obtained from Bio-Synthesis and purified by HPLC. The purity of the peptide was $>95 \%$. The sequences of $\mathrm{MOG}_{35-55}$ and PLP ${ }_{139-151}$ were MEVGWYRSPFSRVVHLYRNGK and HSLGKWLGHPDKF, respectively.

Induction of EAE with $M O G_{35-55}$ and PLP ${ }_{139-151}$ peptides, and neurobehavioral evaluation. Induction of EAE was performed as previously described (Liu et al., 2006) with modifications. Cxcr2 $2^{+/+}$and $C x c r 2^{-1-}$ mice or $\mathrm{Cxcr} 2^{+/+}$and $\mathrm{Cxcr} 2^{-1-}$ bone marrow radiation chimeric mice of $8-10$ weeks of age were subcutaneously injected with different doses of $\mathrm{MOG}_{35-55}$ emulsified in complete Freund's adjuvant (CFA) (Difco Laboratories) containing $400 \mu \mathrm{g}$ of Mycobacterium tuberculosis with two injections of $200 \mathrm{ng}$ of pertussis toxin (PTX) (Sigma-Aldrich) on days 0 and 2 postimmunization (p.i.). Chronic EAE in SWXJ mice was induced with PLP ${ }_{135-151}$, as described previously (Liu et al., 2006). All mice were weighed, examined, and graded daily for neurological signs in a blinded manner as follows: 0 , no disease; 1 , decreased tail tone or slightly clumsy gait; 2 , tail atony and moderately clumsy gait and/or poor righting ability; 3 , limb weakness; 4 , limb paralysis; and 5 , moribund state. Disease re- lapse was determined when an increase of one EAE score unit was observed. Signs of neurological impairment were typically accompanied by an abrupt, substantial weight loss $(>7 \%)$. The average day of EAE onset was calculated by adding the first day of clinical signs for individual mice and dividing by the number of mice in the group. The EAE index was calculated by adding all of the daily EAE scores to obtain a cumulative score, and dividing by day of EAE onset (Liu et al., 2006). Active immunization with $\mathrm{MOG}_{35-55}$ induced monophasic EAE in $\mathrm{B} 6$ mice and was followed for $30 \mathrm{~d}$. Chronic relapsing EAE induced by PLP $_{139-151}$ was also monitored for $30 \mathrm{~d}$. Animals were killed if found to be worse than grade 4. We took a conservative approach and eliminated animals that scored 5 on the day of killing. Water-soaked food was provided on the cage floor when animals reached grade 3 or worse. Deaths before day 7 p.i. were attributed to reaction to immunization or injection of PTX, not EAE.

Araldite embedding, toluidine blue staining, and electron microscopy. Mice were transcardially perfused with ice-cold $0.1 \mathrm{M}$ PBS, followed by $4 \%$ paraformaldehyde (PFA) solution under anesthesia. Spinal cords were rapidly dissected and cut into two pieces at three comparable levels (cervical, thoracic, and lumbar). One of them was postfixed in PBS containing $4 \%$ PFA overnight at $4^{\circ} \mathrm{C}$ for immunohistochemical staining, and for the other 1-mm-thick sections were immediately fixed in PBS containing $4 \%$ PFA and $2.5 \%$ glutaraldehyde for 1 week at $4^{\circ} \mathrm{C}$ for ultramicroscopy. These sections were then postfixed in $1 \%$ osmium tetroxide for $2 \mathrm{~h}$ at room temperature and then dehydrated in a graded series of methanol baths and embedded in Araldite resin according to the previously described protocol (Liu et al., 2010). One-micrometer-thick sections were cut from the Araldite-embedded material, stained with $1 \%$ toluidine blue for light microscopy, and delineated for ultrathin sections. The strategy for analyzing tissue damage in matched semithin sections of lumbar spinal cord is shown schematically in Figure $3 B$. The total white matter area and the demyelinated area in the lumbar spinal cord were measured by ImageJ software (http://rsb.info.nih.gov/ij/). The percentage of demyelinated area was calculated by normalizing the demyelinated area against the total white matter area. The histological analysis was performed by a researcher blinded to the experimental group. For cuprizone-treated mice, midsagittal 1-mm-thick sections through the anterior corpus callosum were embedded in Araldite for electron microscopy. For electron microscopy, $80 \mathrm{~nm}$ sections were cut, mounted on copper grids, stained with uranyl acetate and lead citrate, and examined with a Zeiss $10 \mathrm{C}$ electron microscope. Representative areas were photographed (Liu et al., 2010).

Flow cytometry. Peripheral blood cells were lysed in red blood cell lysis buffer $\left(0.15 \mathrm{M} \mathrm{NH}_{4} \mathrm{Cl}, 1.0 \mathrm{M} \mathrm{KHCO}_{3}, 0.1 \mathrm{~mm}\right.$ EDTA.2Na) for $5 \mathrm{~min}$ and were washed and resuspended in FACS buffer ( $1 \%$ FCS and $0.1 \%$ sodium azide in PBS). After blocking with CD16/CD32 Abs at $4^{\circ} \mathrm{C}$ for $30 \mathrm{~min}$, cells were stained for surface markers with directly conjugated $\mathrm{Abs}$ in FACS buffer at $4^{\circ} \mathrm{C}$ for $30 \mathrm{~min}$. Cells were washed twice and resuspended in the $200 \mu \mathrm{l}$ of PBS for flow cytometry analysis as described previously (Liu et al., 2006). Antibodies used in our experiments were PE-I-A/I-E $\mathrm{mAb}$ (M5/114.15.2; BD Biosciences) and FITC I- ${ }^{\mathrm{k}} \mathrm{mAb}$ (10-3.6; BD Biosciences). For peripheral blood myeloid cell expression of CXCR2, FITC-Gr1Ab (BD Biosciences Pharmingen) PE-CXCR2 Ab (R\&D Systems) were used (Liu et al., 2010). Analysis was performed with a FACSCalibur (BD Biosciences) equipped with CellQuest software (BD Biosciences), and 50,000 events were acquired. Data were analyzed with FlowJo software (Tree Star). The percentages of myeloid cells positively stained for CXCR2 were determined.

Immunohistochemistry and quantification. For histological and immunohistochemical analysis of CNS tissues at different stages of EAE and different time points of cuprizone treatment and lysolecithin injection, mice were transcardially perfused with ice-cold PBS, followed by $4 \%$ PFA solution, under anesthesia. Brains and spinal cords were rapidly dissected and postfixed in $4 \% \mathrm{PFA}$, and then washed with PBS and put in cryoprotection buffer at least overnight at $4^{\circ} \mathrm{C}$ until the tissues sank, and then $30-\mu \mathrm{m}$-thick coronal sections of the brain and transverse sections of spinal cord were cut on a sliding microtome (Leica Microsystems) and kept in cryostorage buffer at $-20^{\circ} \mathrm{C}$ for additional experiments. For immunostaining, sections were pretreated as necessary in a water bath $\left(90^{\circ} \mathrm{C}\right)$ for $20 \mathrm{~min}$ in sodium citrate antigen retrieval buffer (Dako), $\mathrm{pH}$ 
6.0, and then cooled for $30 \mathrm{~min}$. For the staining process, prepared tissues were incubated with $0.3 \%$ hydrogen peroxide in $3 \%$ Triton X-100, blocked by incubation with $5 \%$ normal serum at room temperature for $1 \mathrm{~h}$, and then incubated overnight at $4^{\circ} \mathrm{C}$ with primary antibodies at the dilution indicated: rat anti-mouse CD45 monoclonal antibodies, 1:2000 (clone MCA 1388; Serotec); rabbit anti-rat/mouse PDGF receptor $\alpha$ (PDGFR $\alpha$ ) polyclonal antibodies (to identify OPCs) (1:2000; gift from Dr. William Stallcup, Burnham Institute for Medical Research, La Jolla, CA); proliferating cell nuclear antigen (PCNA) antibody (PC10; cell proliferation marker; Sigma-Aldrich); polysialylated neural cell adhesion molecule (PSA-NCAM) antibody (1:1000; Millipore Bioscience Research Reagents); Olig2 antibody (1:1000; Millipore Bioscience Research Reagents); glutathione $S$-transferase- $\pi$ (GST- $\pi$ ) antibody (1:20,000; Assay Designs), and GFAP antibody (1:8000; Sigma-Aldrich). On day 2, tissues were incubated with appropriate biotinylated secondary antibodies (goat anti-rat, goat anti-mouse, or goat anti-rabbit) (Dako; 1:1000), and then with ABC (Dako; 1:1000). Sections were washed three times with PBS after each incubation step (except for goat serum). All antibodies, as well as ABC, were diluted in $1 \%$ BSA in PBS. Sections were developed with $\mathrm{DAB}$ with hydrogen peroxide for $5 \mathrm{~min}$ at room temperature. After development with $\mathrm{DAB}$, tissues were rinsed in $\mathrm{ddH}_{2} \mathrm{O}$, dehydrated, and mounted. Negative controls were incubated with preimmune $\operatorname{IgG}$ (Sigma-Aldrich). For immunofluorescence staining, Alexa 594-antirabbit antibody, Alexa 488-anti-mouse antibody, or 647-streptavidin (Invitrogen) were used instead of $\mathrm{ABC}$ development.

The quantification of percentage area occupied by immunoreactivity, the number of cells in lesions (number per unit area), or percentage of immunoreactive cells among total cells were performed as previously described (Liu et al., 2006, 2010).

Cuprizone treatment. Cxcr2 $2^{+1+}$ or $C x c r 2^{-1-}$ bone marrow radiation chimeric mice in C57BL/ 6 background mice of $8-10$ weeks of age were fed a diet of pellet mouse chow (diet TD.06172; Harlan Teklad) containing $0.2 \%(\mathrm{w} / \mathrm{w})$ cuprizone (biscyclohexane oxaldihydrazone; SigmaAldrich) ad libitum for a period of 4, 5, or 6 weeks to induce CNS demyelination. Mice were maintained on the cuprizone diet until perfused for analysis or returned to normal chow for 3,7 , or $10 \mathrm{~d}$ for remyelination. $\mathrm{CxCr} 2^{+/+}$or $\mathrm{Cxcr} 2^{+/-}$mice and $\mathrm{Cxcr} 2^{+/+}$or $\mathrm{CxCr} 2^{-/-}$bone marrow radiation chimeric mice without cuprizone feeding were used as controls (Liu et al., 2010). Mice were weighed twice a week, and we did not find a continuous weight loss after 1 week. Control mice were maintained on a normal diet for the duration of the experiment.

Black-Gold histochemical staining for myelin and quantification of demyelination area. Cross sections of spinal cords from EAE mice, and coronal sections of brain from cuprizone treated mice were stained for myelin by using Black-Gold solution (Millipore Bioscience Research Reagents). The Black-Gold histochemical staining was performed according to the manufacturer's protocol with modifications. Briefly, freefloating sections were washed with $0.9 \% \mathrm{NaCl}$, and then incubated in $0.2 \%$ Black-Gold solution at $65^{\circ} \mathrm{C}$ in a water bath for $10 \mathrm{~min}$, rinsed for 2 $\min$ in $0.9 \% \mathrm{NaCl}$, fixed for $3 \mathrm{~min}$ in a $2 \%$ sodium thiosulfate solution, and rinsed in $0.9 \% \mathrm{NaCl}$ three times (Liu et al., 2010). Sections were mounted on slides and dehydrated at $60^{\circ} \mathrm{C}$ for $30 \mathrm{~min}$, cleared in xylenes, and coverslipped with Permount media (Sigma-Aldrich). Corpus callosum area was digitized under a $5 \times$ objective, using a 3 -CCD color video camera interfaced with an Image-Pro Plus Analysis System (4.1.0.0 version; MediaCybernetics). For comparison of results obtained in CXCR $2^{+/+}$and CXCR2 ${ }^{-1-}$ bone marrow chimeric mice, levels of brain sections were carefully matched. Digitized images were analyzed with $\mathrm{NIH}$ ImageJ1.34s software. A threshold procedure was established to determine the proportion of Black-Gold staining area within each gated corpus callosum area. These parameters were then held constant for each set of images obtained at equal objectives and light intensities, on slides that were processed in one session. The data represent the mean area occupied by demyelinated tissue (void of Black-Gold staining), expressed as a percentage of total corpus callosum or dorsal column area.

In vitro cerebellum slice cultures and LPC treatment. Postnatal day 10 (P10) mice pups were killed, and the cerebellums were removed and placed in ice-cold Hanks buffer (Invitrogen). Four hundredmicrometer-thick sagittal sections were cut by microtome (Leica VT

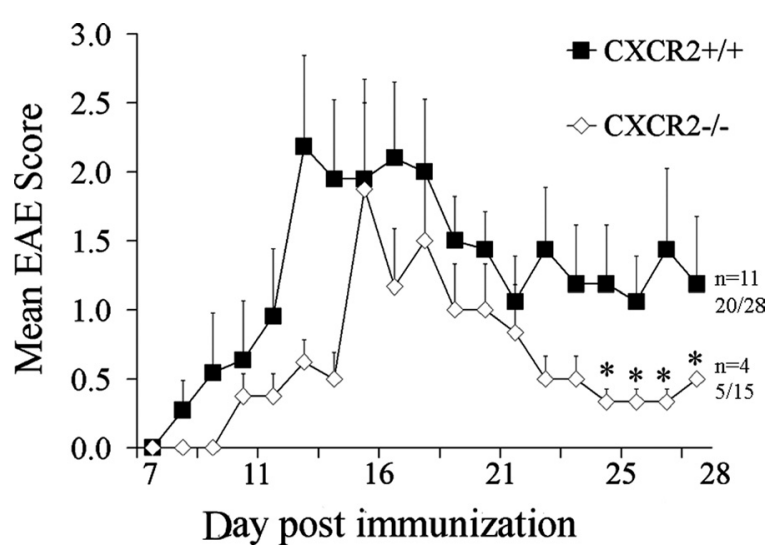

Figure 1. Global CXCR2 deficiency dramatically reduces susceptibility to EAE and enhances recovery in SWXJ mice. CXCr2 ${ }^{+1+}(n=11)$ or CXCr2 $2^{-1-}$ mice $(n=4)$ on SWXJ background were immunized with $150 \mu \mathrm{g}$ of $\mathrm{PLP}_{139-151}$ peptide emulsified in CFA containing $400 \mu \mathrm{g}$ of Mycobacterium tuberculosis. A total of $200 \mathrm{ng}$ of PTX was injected on day 0 and 2 postimmunization. EAE onset, kinetics, mortality, and peak severity in $\mathrm{XxC}^{-1-}$ mice that became ill were all equivalent to that seen in $C x c r 2^{+1+}$ littermates. Interestingly, recovery from the initial attack of EAE was faster and more complete in $\left(x \mathrm{Cr} 2^{-1-}\right.$ mice between 24 and $28 \mathrm{~d}$ after immunization. ${ }^{*} p<0.05$. Graph is from one (of three) representative experiment (total Cxcr2 $2^{+1+}$ mice, $n=28 ;\left(x c r 2^{-1-}\right.$ mice, $\left.n=15\right)$. Error bars indicate SEM.

1000S; Leica). Two to three slices were plated on Falcon six-well insert plates (Thermo Fisher Scientific) previously coated with $1 \mathrm{mg} / \mathrm{ml}$ collagen (Sigma-Aldrich) with a drop of complete media (50\% DMEM/F12, $25 \%$ Hanks buffer, $25 \%$ horse serum, and $5 \mathrm{mg} / \mathrm{ml}$ glucose) on top of it for $4-6 \mathrm{~h}$, and then $500 \mu \mathrm{l}$ of the same media was added on top of the insert chamber and $1.5 \mathrm{ml}$ of media in the outside insert chamber. Demyelination was performed with $0.25 \mathrm{mg} / \mathrm{ml}$ lysolecithin (SigmaAldrich) in complete media with the same concentration of control rabbit antibody, CXCR2 antibody or media alone for $17 \mathrm{~h}$, and then fresh media with or without control rabbit antibody or CXCR2 antibody was administered for $2 \mathrm{~d}$ to allow remyelination. For evaluation of demyelination and remyelination, the slices were immunostained for myelin (mouse anti-MBP antibody) and neurofilament (rabbit anti-neurofilament antibody). The slices were washed with $1 \times$ PBS and fixed in $4 \%$ PFA at room temperature for $20 \mathrm{~min}$, and then washed three times with PBST $(0.05 \%$ Triton X-100 in $1 \times$ PBS), permeabilized in $10 \%$ Triton X-100 at room temperature for $20 \mathrm{~min}$, and blocked with blocking buffer $\left(3 \% \mathrm{H}_{2} \mathrm{O}_{2}, 1 \% \mathrm{BSA}\right.$, and $10 \%$ goat serum $)$ at room temperature for $2 \mathrm{~h}$. After that, the slices were incubated with MBP antibody and neurofilament antibody at $4^{\circ} \mathrm{C}$ overnight, and incubated with Alexa 488goat anti-mouse and Alexa 594-goat anti-rabbit antibody (1:1000; Invitrogen) at room temperature for $1 \mathrm{~h}$ the following day. After three washes, slices were mounted on the slides to obtain pictures. Doubleblind scoring of demyelination was based on the extent of myelination: 0 , no myelination; 1, one-half myelination; 2, complete myelination.

Statistics. Data are expressed as mean \pm SD. Multiple comparisons were statistically evaluated by one-way ANOVA using Prism 4 (GraphPad Software). The Student $t$ test was used for the comparisons of disease severity, severity of pathological changes, and percentage area of immunoreactivity in comparisons between $\mathrm{CxCr} 2^{+1+}$ and $\mathrm{Cxcr} 2^{-1-}$ mice. A $\chi^{2}$ test was used for the comparisons of disease incidence or mortality between $C x c r 2^{+/+}$and Cxcr $2^{-l-}$ mice. A value of $p<0.05$ was considered to be significant. ${ }^{\star} p<$ $0.05 ;{ }^{* *} p<0.01$.

\section{Results}

Global CXCR2 deficiency dramatically reduces susceptibility and enhances recovery in two EAE models

Although BALB/c mice lacking CXCR2 were resistant to induction of EAE (Carlson et al., 2008), the EAE score and severity were relatively mild in $\mathrm{BALB} / \mathrm{c}$ background $\mathrm{Cxcr} 2^{+/+}$control mice. To extend understanding of the role of CXCR2 in EAE, we developed additional genetic models. $\mathrm{Cxcr} 2^{-1-} \mathrm{BALB} / \mathrm{c}$ mice were back- 
Table 1. EAE induction in $\mathrm{CxCr} 2^{+/+}$and $\mathrm{CxCr} 2^{-/-}$mice

\begin{tabular}{|c|c|c|c|c|c|c|c|}
\hline Strain & Peptide & Genotype & Incidence & Mortality & Day of onset & Day of peak EAE & Mean max score \\
\hline SWXJ & $\mathrm{PLP}_{139-151}$ & $C x C r 2^{+1+}$ & $20 / 28(71 \%)$ & $3 / 28(11 \%)$ & $13.1 \pm 3.1$ & $14.4 \pm 2.8$ & $3.6 \pm 1.3$ \\
\hline SWXJ & $\mathrm{PLP}_{139-151}$ & $\left(x \mathrm{Cr} 2^{-1-}\right.$ & $5 / 15(33 \%)^{a, b * *}$ & $2 / 15(13 \%)$ & $13.3 \pm 2.4$ & $14.7 \pm 2.1$ & $3.2 \pm 1.4$ \\
\hline C57BL/6 & $\mathrm{MOG}_{35-55}$ & $\left(x \mathrm{Cr} 2^{+1+}\right.$ & $7 / 8(87 \%)$ & $0 / 8(0 \%)$ & $15.3 \pm 3.1$ & $16.3 \pm 2.1$ & $3.17 \pm 1.0$ \\
\hline C57BL/6 & $\mathrm{MOG}_{35-55}$ & $C x C r 2^{-1-}$ & $0 / 5(0 \%)^{c * *}$ & $0 / 5(0 \%)$ & I & I & I \\
\hline
\end{tabular}

Mean max score, Mean maximum EAE score.

${ }^{a}$ Nine $\mathrm{CxCr}^{-1-}$ mice and 'three $\mathrm{C} x \mathrm{Cr} 2^{-1-}$ mice that died within day 7 p.i. were not calculated as total number for incidence.

${ }^{b}$ Data represent pooled results from three experiments; there is a significant difference $(p<0.05)$ in cumulative EAE score between $C x c r 2^{+/+}(26.0 \pm 10.5)$ and $C x c r 2^{-1-}(14.8 \pm 7.4)$.

${ }^{* *} p<0.01$, compared with the wild-type controls.

crossed to SWR and SJL/J background for nine generations; SWR $\mathrm{Cxcr} 2^{+/-}$mice were crossed with SJL/J Cxcr2 $2^{+/-}$mice to obtain littermate $\mathrm{Cxcr} 2^{+/+}, \mathrm{Cxcr} 2^{+/-}$, and $\mathrm{Cxcr} 2^{-1-}$ SWXJ mice for experiments ( $\mathrm{Yu}$ et al., 1996). Mice used for EAE studies were genotyped by analysis of tail DNA and additionally analyzed by flow cytometry to ensure the $\mathrm{H} 2^{\mathrm{q} / \mathrm{s}}$ haplotype in SWXJ mice. The $\mathrm{Cxcr2} 2^{-1-}$ allele was also backcrossed to the C57BL/6 (B6) background for 11 generations. In the susceptible SWXJ and B6 backgrounds, Cxcr $2^{-1-}$ mice were relatively resistant to developing EAE, with a particularly low incidence of disease (Fig. 1, Table 1). In three separate experiments, we immunized a total of 24 CXcr2 $2^{-1-}$ mice in SWXJ background with PLP $_{139-151}$ peptides, of which 9 died shortly after immunization and were removed from analysis. Only 5 of $15(33 \%)$ surviving $C x c r 2^{-1-}$ mice developed EAE, compared with 20 of $28(71 \%) C x c r 2^{+/+}$littermates $(p<$ $0.01)$. EAE day of onset, kinetics, mortality, and peak severity in $\mathrm{Cxcr} 2^{-1-}$ mice that became ill were all equivalent to that seen in Cxcr $2^{+/+}$littermates (Fig. 1, Table 1$)(p>0.05)$. Interestingly, recovery from the initial attack of EAE was faster and more complete in $\mathrm{Cxcr} 2^{-1-}$ mice, and severity scores in the resolution phase were significantly lower than in $C x c r 2^{+/+}$mice $(p<0.05)$, which caused a decreased cumulative EAE score in $C x \mathrm{cr} 2^{-1-}$ compared with Cxcr2 $2^{+1+}$ littermates (Fig. 1, Table 1). Cxcr2 $2^{-1-}$ mice on B6 background were also relatively resistant to MOG-induced EAE: $87 \%$ incidence in $C x c r 2^{+/+}$mice, whereas 0 of $5(0 \%)$ of $C x c r 2^{-1-}$ mice that survived beyond day 7 after immunization developed EAE (Table 1$)(p<0.01)$. Our findings extend results from a recent report (Carlson et al., 2008) to EAE-susceptible mice and further confirm that CXCR2-deficient mice are relatively resistant to induction of EAE. Moreover, we observed better recovery in $\mathrm{CxCr}^{-1-}$ mice after the initial EAE attack.

\section{Cxcr2 ${ }^{+/-} \rightarrow \mathrm{CxCr}^{-1-}$ mice with CXCR2 deficiency in the CNS are fully susceptible to EAE but recover more quickly and more completely}

$\mathrm{CXcr} 2^{-1-}$ mice are relatively resistant to EAE in two different strains. These results left uncertain whether resistance to EAE in $\mathrm{Cxcr} 2^{-1-}$ mice was mediated solely by hematopoietic cells or whether altered CXCR2 expression on resident neuroepithelial cells also played a role. Addressing these questions was challenging because the expression of CXCR2 on neutrophils as well as OPCs could mediate diverse effects on lesion-associated tissue injury. To address this issue, we generated $\mathrm{Cxcr} 2^{+/-} \rightarrow \mathrm{CxCr} 2^{-1-}$ and $\mathrm{Cxcr} 2^{+/-} \rightarrow \mathrm{CxCr} 2^{+/+}$bone marrow chimeric mice for EAE experiments. $\mathrm{Cxcr} 2^{+1+} \rightarrow \mathrm{Cxcr} 2^{+/+}$ mice served as chimerism controls. We lethally irradiated both $\mathrm{CxCr} 2^{+/+}$and $\mathrm{CxCr} 2^{-1-}$ mice and transferred $\mathrm{CxCr} 2^{+/-}$bone marrow. $\mathrm{CxCr} 2^{+/-} \rightarrow \mathrm{CxCr}^{-1-}$ mice lacked CXCR2 on OPCs (and other nonradioresistant cells). Both chimerae expressed CXCR2 on hematopoietic cells (Liu et al., 2010). Engraftment of $\mathrm{Cxcr} 2^{-/-}$mice was verified by demonstrating normalization of circulating myeloid cells by flow cytometry (Liu et al., 2010).

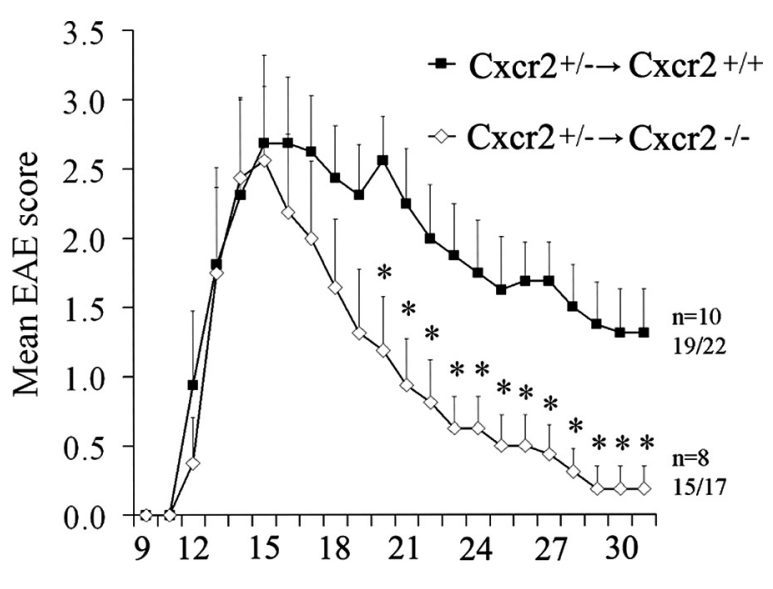

Day post immunization

Figure 2. PLP ${ }_{139-151}$-induced EAE in SWXJ $\mathrm{CxCr}_{\mathrm{C} 2}{ }^{+/-} \rightarrow \mathrm{CXCr}^{-1-}$ or $\mathrm{CXCr}^{+/-} \rightarrow \mathrm{CXCr}^{+/+}$ bone marrow chimeric mice. $\mathrm{CxCr}^{+1-} \rightarrow \mathrm{CxCr}^{-1-}$ mice or $\mathrm{CxCr} 2^{+1-} \rightarrow \mathrm{CxCr}^{+/+}$were immunized with $150 \mu \mathrm{g}$ of $\mathrm{PLP}_{139-151}$ peptide emulsified in CFA containing $400 \mu \mathrm{g}$ of Mycobacterium tuberculosis. A total of $200 \mathrm{ng}$ of PTX was injected on day 0 and 2 postimmunization. $\mathrm{CXCr}^{+/-} \rightarrow$ $\mathrm{CxCr}^{-1-}$ and $\mathrm{CxCr}^{+/-} \rightarrow\left(\mathrm{XCr}_{2}{ }^{+/+}\right.$bone marrow chimeric mice developed EAE with indistinguishable incidence, kinetics, and severity, but $\mathrm{Cxcr}^{+1-} \rightarrow\left(x_{\mathrm{Cr}}\right)^{-1-}$ recovered more quickly and completely than did $\mathrm{CXCr}^{+1-} \rightarrow \mathrm{XCr}^{+/+}$mice, showing significantly lower EAE severity scores between days 20 and 30 postimmunization. ${ }^{*} p<0.05$. Graph is from one (of three) representative experiment (total $\mathrm{CxCr}^{+/-} \rightarrow \mathrm{CxCr}^{-1-}$ mice, $n=17 ; \mathrm{CxCr}^{+/-} \rightarrow\left(\mathrm{x} \times \mathrm{rr} 2^{+/+}\right.$mice, $\left.n=22\right)$. Error bars indicate SEM.

To investigate the role of CXCR2-expressing cells in the CNS, we immunized bone marrow chimeric mice that lacked CNS CXCR2 $\left(\mathrm{Cxcr} 2^{+/-} \rightarrow \mathrm{CxCr} 2^{-/-}\right)$and controls $\left(\mathrm{Cxcr} 2^{+/-} \rightarrow \mathrm{CxCr} 2^{+/+}\right)$using $\mathrm{PLP}_{139-151}$. In three separate experiments, we immunized a total of $22 \mathrm{Cxcr} 2^{+1-} \rightarrow \mathrm{CxCr}^{-1-}$ or $\mathrm{Cxcr} 2^{+/-} \rightarrow \mathrm{CxCr} 2^{+/+}$mice, of which 5 of the $22 \mathrm{Cxcr}^{+1-} \rightarrow \mathrm{Cxcr} 2^{-1-}$ died shortly after immunization and were removed from analysis. We found $\mathrm{CxCr} 2^{+1-} \rightarrow \mathrm{CxCr} 2^{-1-}$ and $\mathrm{Cxcr} 2^{+/-} \rightarrow \mathrm{CxCr} 2^{+/+}$mice had an equivalent incidence of EAE $(88$ and $86 \%$, respectively) (Fig. 2, Table 2), indicating that the lack of expression of CXCR2 on neutrophils causes reduced incidence of EAE in $\mathrm{Cxcr} 2^{-1-}$ mice. The day of onset, day of peak disease (reflecting kinetics of neurological impairment), and severity of EAE at the peak were all equivalent in both groups of mice (Fig. 2, Table 2). However, as seen previously in $\mathrm{Cxcr} 2^{-1-}$ mice, the pace and extent of recovery were accelerated in mice lacking CXCR2 in the CNS as seen in the cumulative EAE score, which was $27 \pm 13.9$ and $17 \pm 8.7$ in $\mathrm{CxCr} 2^{+1-} \rightarrow \mathrm{Cxcr} 2^{+1+}$ and $\mathrm{Cxcr} 2^{+1-} \rightarrow \mathrm{Cxcr}^{-1-}$, respectively $(p<0.05)$ (Table 2). Neither bone marrow chimerism nor Cxcr2 haploinsufficiency in hematopoietic cells significantly affected the course of EAE since mean EAE severity scores and kinetics in $\mathrm{CxCr} 2^{+/-} \rightarrow \mathrm{CxCr} 2^{+/+}$and $\mathrm{Cxcr} 2^{+/+} \rightarrow \mathrm{CxCr} 2^{+/+}$mice were not different (supplemental Table 1, available at www.jneurosci.org as supplemental material) (data not shown). Previous published results 
Table 2. PLP ${ }_{139-151}$ induced EAE in CXCR2 ${ }^{+/+}$and $\mathrm{CXCR2}^{-/-}$bone marrow radiation chimeric mice ${ }^{a}$

\begin{tabular}{lllllll}
\hline Mice & Incidence $^{b}$ & Mortality & Day of onset & Day of peak EAE & Mean max score & Cumulative EAE score \\
\hline $\mathrm{Cxcr2}^{+/-} \rightarrow \mathrm{Cxcr2}^{+/+}$ & $19 / 22(86 \%)$ & $1 / 22(5 \%)$ & $12.3 \pm 2.5$ & $13.3 \pm 3.1$ & $3.4 \pm 1.1$ & $27 \pm 13.9$ \\
$\mathrm{Cxcr2}^{+/-} \rightarrow \mathrm{Cxcr2}^{-1-}$ & $15 / 17(88 \%)$ & $0 / 17(0 \%)$ & $13.9 \pm 2.8$ & $14.6 \pm 2.1$ & $3.3 \pm 0.9$ & $17 \pm 8.7^{*}$ \\
\hline
\end{tabular}

Mean max score, Mean maximum EAE score. Data represent pooled results from three experiments.

${ }^{a}$ Bone marrow radiation chimeras were done by transferring $1 \times 10^{7}$ bone marrow cells from CXCR2 ${ }^{+1-}$ mice to 900 rad irradiated CXCR2 ${ }^{+/+}$and CXCR2 ${ }^{-1-}$ recipients

${ }^{b}$ Five $\mathrm{CXCR}_{2}{ }^{-1-}$ recipients that died within day 7 p.i. were not calculated as total number for incidence.

${ }^{*} p<0.05$, compared with the wild-type recipients.

showed that haploinsufficiency at CXCR2 produced significantly milder EAE in $\mathrm{Cxcr}^{+/-}$mice (Carlson et al., 2008). The differences between our results and those previously reported may be attributable to the use of a different EAE model, as BALB/C mice [used in the previous study (Carlson et al., 2008)] represent a relatively EAEresistant strain and develop a mild disease.

Cxcr2 $2^{+/-} \rightarrow \mathrm{Cxcr}^{-/-}$mice have equal infiltration and demyelination as Cxcr2 $2^{+/-} \rightarrow \mathrm{CxCr}^{+/+}$mice at the peak of EAE but repair better during the recovery stage

Next, we tested the hypothesis that milder EAE severity scores reflected improved tissue repair. Toluidine blue-stained semithin spinal cord sections were prepared to address this possibility by identifying remyelinated segments with thin myelin sheaths. We found that altered developmental myelin thickness in $\mathrm{Cxcr} 2^{-1-}$ mice (Padovani-Claudio et al., 2006) precluded this approach. Therefore, we quantified lesion area by prospective morphometric analysis both at the peak of disease and at the recovery phase by toluidine blue staining on semithin sections to reveal myelin. Cxcr2 $2^{+/-} \rightarrow \mathrm{CxCr}^{+/+}$(Fig. $3 A$, top panel) and $\mathrm{CxCr} 2^{+/-} \rightarrow \mathrm{CxCr} 2^{-1-}$ (Fig. $3 A$, bottom panel) mice at the peak of EAE showed similar lesion areas and pathology. There was extensive myelin debris (arrowhead), activated macrophages (arrow), and degenerating axon cylinders (asterisk) in the lesion areas of both groups (Fig. 3A, middle panel), as predicted by the equivalent disease scores (Fig. 2). However, at the recovery phase (normalized by assaying at day 10 after peak EAE score), $\mathrm{Cxcr} 2^{+/-} \rightarrow \mathrm{Cxcr} 2^{-1-}$ mice had significantly smaller lesion areas than $C x c r 2^{+/-} \rightarrow C x c r 2^{+/+}$mice (Fig. $3 A, C$ ), consistent with the hypothesis that accelerated repair underlies improved neurological recovery (Fig. 2). Importantly, $\mathrm{CxCr} 2^{+1-} \rightarrow \mathrm{Cxcr} 2^{-1-}$ and $\mathrm{CxCr} 2^{+/-} \rightarrow \mathrm{CxCr}^{+/+}$mice with EAE showed equivalent degrees of inflammation at the peak and recovery phase as monitored by CD45 staining and percentage area occupied by immunoreactivity (Fig. 4). We conclude that myelin repair was unexpectedly enhanced in EAE tissues of mice that lacked CXCR2 on nonhematopoietic cells, despite equivalent degrees of initial inflammation and tissue injury. These results also support the hypothesis that CXCR2 expressed in myeloid cells is critical to the induction of EAE, but not to its repair.
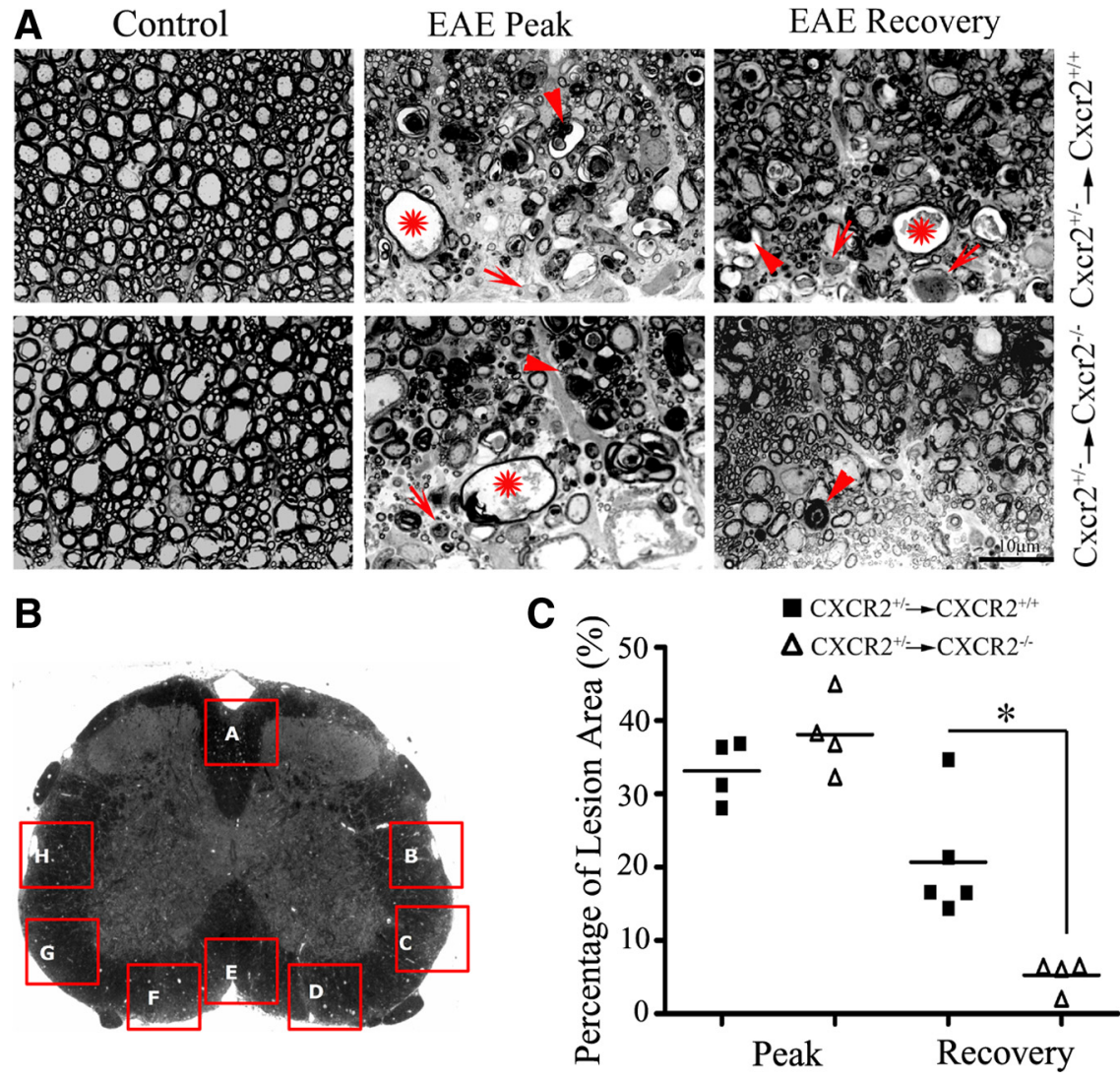

Figure 3. $\quad\left(x \mathrm{Cr} 2^{+1-} \rightarrow C x C r 2^{-1-}\right.$ mice show robust myelin repair after EAE. $\boldsymbol{A}$, The $1 \mu \mathrm{m}$ semithin sections were stained with toluidine blue using matched spinal cord sections from mock-immunized controls, at peak of EAE or at recovery. Top, $C x c r 2^{+/-} \rightarrow$ or without myelin debris. The asterisk shows degenerating axon cylinders. Scale bar, $10 \mu \mathrm{m}$. $\boldsymbol{B}$, Lesion area quantification scheme. Tissue injury in eight predefined $(\mathrm{A}-\mathrm{H})$ white matter regions in each section were outlined by a blinded observer and quantified using NIH ImageJ. C, Quantification results demonstrated the similar lesion area at the peak of EAE between two groups; however, less lesion area in $\mathrm{CxCr} 2^{+1-} \rightarrow \mathrm{CxCr} 2^{-1-}$ mice at recovery stage. ${ }^{*} p<0.05$. Data represent two experiments.

CXCR2 deficiency in the CNS accelerated remyelination in a cuprizone-induced demyelination model

Demyelination and remyelination in EAE occur stochastically throughout the CNS, mediated by complex, incompletely characterized mechanisms. For these reasons, kinetic analysis of myelin repair in EAE lesions is impractical. To address the time course of myelin repair in timed and localized lesions, we used cuprizone feeding for 6 weeks (Matsushima and Morell, 2001; Murtie et al., 2005), which mediates severe demyelination of the corpus callosum, followed by myelin repair within $\sim 2$ weeks after cuprizone cessation. This model also offered the advantage of an extended time course in which to analyze cellular events associated with demyelination and remyelination. We performed analysis of demyelination in $\mathrm{Cxcr2} 2^{+/-} \rightarrow \mathrm{CxCr} 2^{-1-}$ and $\mathrm{Cxcr} 2^{+/-} \rightarrow \mathrm{Cxcr} 2^{+/+}$ mice and found that $\mathrm{CxCr} 2^{+-} \rightarrow \mathrm{CxCr}^{-1-}$ and $\mathrm{CxCr} 2^{+-} \rightarrow$ $\mathrm{Cxcr} 2^{+/+}$mice showed equivalent severe demyelination of the cor- 
A Control

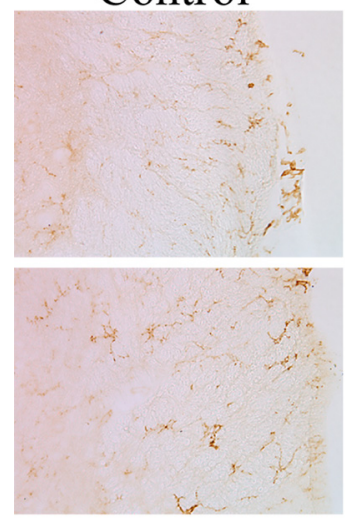

B

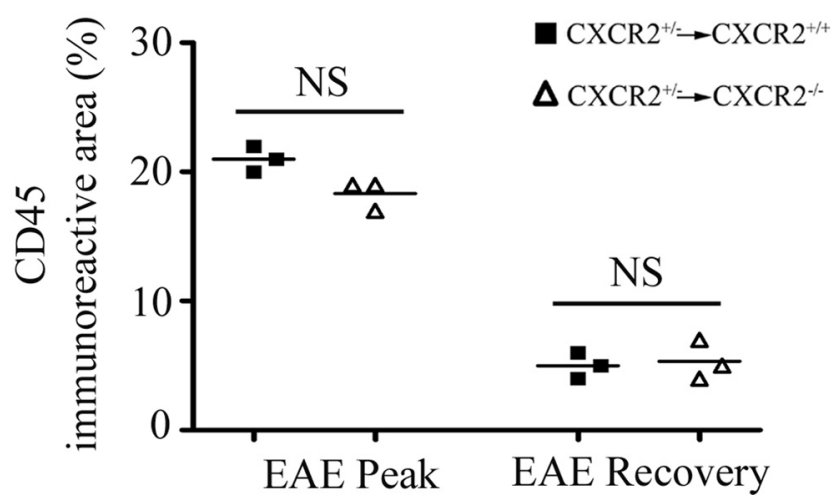

Figure 4. CXCr2 ${ }^{+/-} \rightarrow \mathrm{CXCr}^{-1-}$ mice show equivalent cellular inflammation as $\mathrm{CXCr}^{+/-} \rightarrow \mathrm{XXC2}^{+/+}$mice at the peak of EAE. $A_{t}$ $\mathrm{CXCr}^{+1-} \rightarrow \mathrm{CxC2}^{-1-}$ (bottom) and $\mathrm{CxCr}^{+/-} \rightarrow \mathrm{CXCr}^{+/+}$(top) mice with EAE showed equivalent degrees of inflammation at the peak of EAE and recovery phase as monitored by CD45 staining. B, Quantification of CD45-immunoreactive area. Scale bar: $A, 50 \mu \mathrm{m}$. NS, Not significant $(p>0.05)$.

pus callosum after 4, 5 (data not shown), or 6 weeks of cuprizone feeding (Liu et al., 2010) as monitored by quantitative histochemical Black-Gold staining (Fig. 5A-C). After removing the cuprizone food after 6 weeks of cuprizone feeding, $\mathrm{Cxcr} 2^{+/-} \rightarrow \mathrm{Cxcr} 2^{-1-}$ and $\mathrm{CxCr} 2^{+/-} \rightarrow \mathrm{CxCr}^{+/+}$mice showed equivalent severe demyelination of the corpus callosum at day 3 after removing cuprizone food (Fig. 5A,C) $(p>0.05)$. However, Cxcr $2^{+/-} \rightarrow C x c r 2^{-1-}$ mice showed dramatically enhanced myelin staining compared with $\mathrm{CxCr} 2^{+/-} \rightarrow \mathrm{CxCr}^{+/+}$mice at days 7 and 10 of recovery (Fig. $5 A, C)(p<0.05)$. Electron microscopy also showed significantly increased numbers of myelinated axons in $\mathrm{Cxcr} 2^{+/-} \rightarrow \mathrm{Cxcr} 2^{-1-}$ mice, compared with $\mathrm{Cxcr} 2^{+/-} \rightarrow \mathrm{Cxcr} 2^{+/+}$mice at day 10 of recovery (Fig. $5 D, E)(p<0.05)$, confirming the histochemical staining results in these mice. There was no difference in the corpus callosum area between $\mathrm{CxCr} 2^{+/-} \rightarrow \mathrm{Cxcr} 2^{+/+}$and $\mathrm{CxCr} 2^{+/-} \rightarrow \mathrm{CxCr} 2^{-/-}$mice at the times of killing (Fig. $5 B)(p>0.05)$. Collectively, these data support the hypothesis that CXCR2 expression on CNS cells impaired myelin repair.

\section{$\mathrm{CXCR}^{+/-} \rightarrow \mathrm{CXCR}^{-/-}$mice generate oligodendrocytes after} demyelination more quickly than $\mathrm{CXCR} 2^{+/-} \rightarrow \mathrm{CXCR}^{+/+}$mice; there is no enhancement of neural stem cell proliferation, but OPCs divide more rapidly in demyelinated lesions

How does CXCR2 signaling to CNS cells inhibit remyelination? There are multiple potential cellular targets (supplemental Fig. 1, available at www.jneurosci.org as supplemental material). For example, GFAP-positive neural stem cells (NSCs) in the adult subventricular zone (SVZ) can give rise to oligodendrocytes, which participate in the repair of the demyelinated corpus callo- sum (Nait-Oumesmar et al., 1999; Menn et al., 2006). The SVZ neurogenic niche is comprised of slowly dividing GFAP+ NSCs, rapidly dividing transit-amplifying cells, and migrating cells including neuroblasts. The migrating cells are labeled by antibodies to PSA-NCAM. A small proportion of migrating cells express the oligodendroglial transcription factor Olig2 and can give rise to GST- $\pi+$ oligodendrocytes. The yield of oligodendrocytes from the SVZ is increased fourfold after lysolecithin-mediated demyelination of the nearby rostral corpus callosum and in vivo retroviral labeling showed that SVZ cells contribute to remyelinating oligodendrocytes (Menn et al., 2006). The SVZ exhibits altered cytoarchitecture consistent with activation of the NSCs in both MS and EAE (Nait-Oumesmar et al., 1999).

To address the role of CNS CXCR2+ cells in remyelination, we performed kinetic analysis of NSCs and their progeny in the SVZ and the corpus callosum across the time course of demyelination and remyelination after cuprizone feeding of radiation bone marrow chimeric mice (Fig. 6; supplemental Fig. 1, available at www.jneurosci.org as supplemental material). $\mathrm{CxCr} 2^{+/-} \rightarrow \mathrm{CxCr}^{+/+}$and $\mathrm{Cxcr} 2^{+1}$ $\rightarrow \mathrm{CxCr} 2^{-1-}$ mice were fed cuprizone for 4 , 5 , or 6 weeks before killing. Additional mice were fed cuprizone for 6 weeks and recovered without cuprizone feeding for 3 or $7 \mathrm{~d}$ before killing. At least three $\mathrm{CxCr} 2^{+/-} \rightarrow \mathrm{CxCr}^{+/+}$and $\mathrm{Cxcr} 2^{+/-} \rightarrow \mathrm{Cxcr} 2^{-1-}$ mice were analyzed at each time point. Analyses were performed in a blinded fashion and included GFAP+ NSCs in the SVZ and PSA-NCAM+ migrating cells in the lateral corpus callosum. In the corpus callosum, we quantified PDGFR $\alpha+/ \mathrm{PCNA}+$ proliferating oligodendrocyte progenitor cells, GST- $\pi+$ mature oligodendrocytes, and Olig2 + cells representing both oligodendrocyte progenitors and mature oligodendrocytes.

Results are shown schematically in supplemental Figure 1 (available at www.jneurosci.org as supplemental material) and Figure 6 as follows: (1) GFAP+ cells in the SVZ were unchanged throughout the experiment, consistent with their status as slowly dividing NSCs; (2) PSA-NCAM + cells in the lateral corpus callosum showed a dramatic biphasic increase, at the same rate and to the same extent, in mice from both groups (supplemental Fig. 1, available at www. jneurosci.org as supplemental material); (3) after 4 weeks of cuprizone feeding, large numbers of PCNA + cells were observed in corpus callosum of $\mathrm{Cxcr} 2^{+/-} \rightarrow \mathrm{CxCr} 2^{-1-}$ and $\mathrm{Cxcr} 2^{+/-} \rightarrow$ Cxcr $2^{+1+}$ mice (Fig. 6A). Few PCNA-immunoreactive cells were observed in the control animals (Fig. 6A). However, by dual-label immunohistochemistry using PCNA and PDGFR $\alpha$, the fraction of PDGFR $\alpha$ cells expressing PCNA was significantly higher (Fig. 6A,C) in Cxcr $2^{+/-} \rightarrow C x c r 2^{-1-}$ mice $(\sim 52 \%)$, compared with $\mathrm{Cxcr} 2^{+/-} \rightarrow \mathrm{Cxcr} 2^{+/+}$mice $(\sim 30 \%)(p<0.05)$. Furthermore, proliferating PDGFR $\alpha$ cells in the corpus callosum of $\mathrm{CxCr} 2^{+-} \rightarrow \mathrm{CxCr}^{-1-}$ mice quickly gave rise to oligodendroglia, with significantly $(p<0.05)$ larger numbers of GST- $\pi+$ oligodendrocytes observed at $3 \mathrm{~d}$ of recovery after 6 weeks of cuprizone feed- 

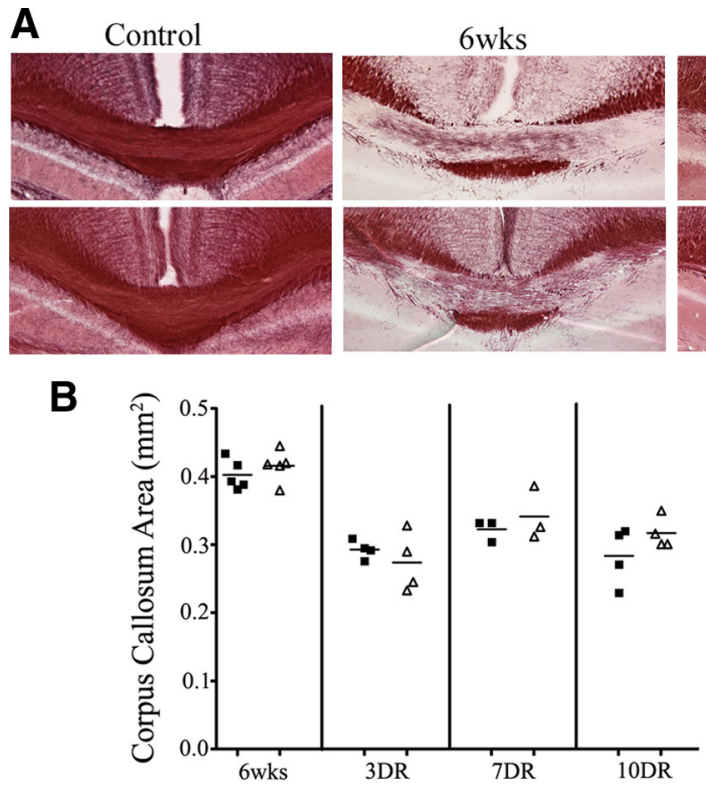

D

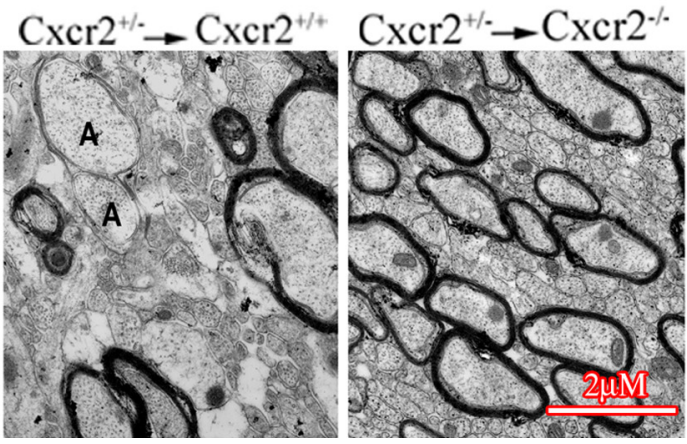

6 wks
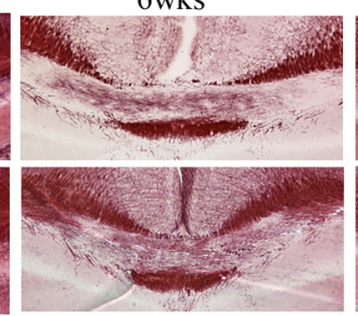

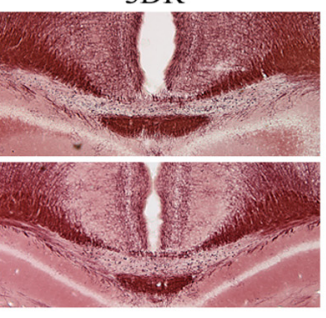

3DR
$7 \mathrm{DR}$
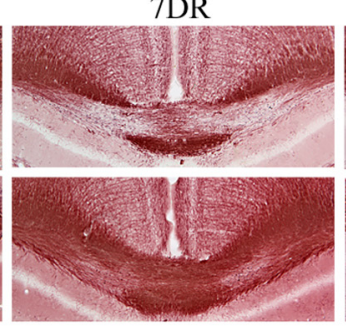

C

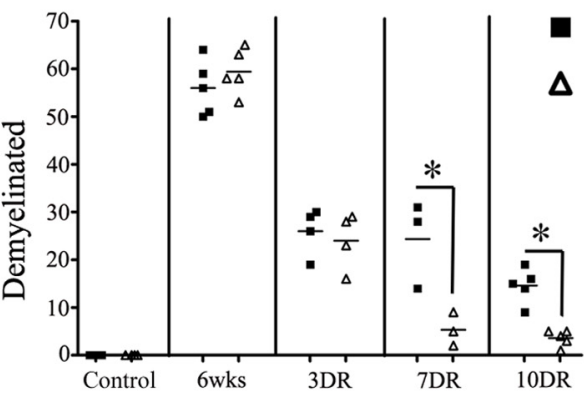

10DR
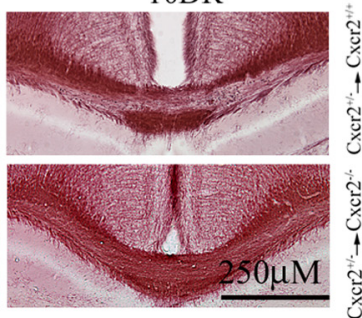

$\mathrm{Cxcr} 2^{+/} \rightarrow \mathrm{Cxcr}^{+/+}$

$\Delta \mathrm{Cxcr}^{+} \stackrel{\rightarrow}{ } \mathrm{Cxcr}^{-}-$

$\mathbf{E}$

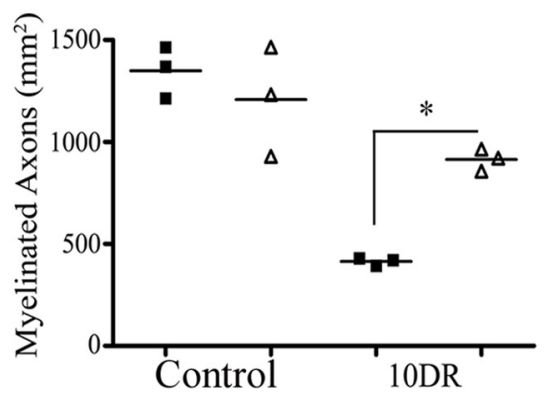

Figure 5. CXCR2 deficiency in CNS dramatically accelerates remyelination in a cuprizone-induced demyelination model. $A, C X C r 2^{+/-} \rightarrow\left(X C r 2^{+/+}\right.$mice (top) and $C X C r 2^{+/-} \rightarrow\left(x C r 2^{-/-}\right.$mice (bottom) were killed after cuprizone feeding for 6 weeks or after recovery for $3 \mathrm{~d}(3 \mathrm{DR}), 7 \mathrm{~d}(7 \mathrm{DR})$, or $10 \mathrm{~d}$ (10DR). Black-Gold myelin staining showed equivalent severe demyelination of the corpus callosum in

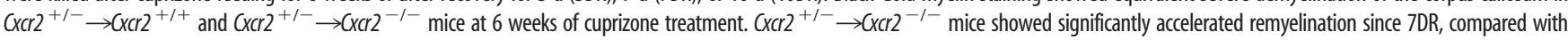
$\mathrm{CxCr}^{+/-} \rightarrow \mathrm{CxCr2}{ }^{+/+}$mice. B, Quantification of corpus callosum area during the cuprizone treatment showed no significant differences between these two groups. $C$, Quantification of percentage of corpus callosum demyelinated showed significant differences in remyelination at 7DR and 10DR time points between $C x \mathrm{Cr} 2^{+/-} \rightarrow\left(x \mathrm{Cr} 2^{+/+}\right.$mice and $\mathrm{CxCr} 2^{+/-} \rightarrow\left(x \mathrm{Cr} 2^{-1-}\right.$ mice. D, Increased number of myelinated axons in $\mathrm{CxCr}^{+/-} \rightarrow \mathrm{CxC2} 2^{-/-}$mice shown by electron microscopy. Ultrathin section of corpus callosum at 10DR after cuprizone feeding of $\mathrm{CxCr}^{+/-} \rightarrow \mathrm{Cxcr}^{+/+}$(left) or $\mathrm{Cxcr2} 2^{+/-} \rightarrow$

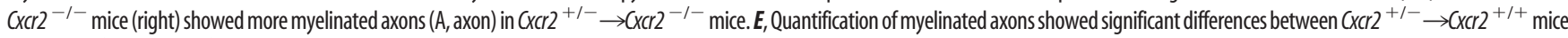
and $\mathrm{XxCr}^{+/-} \rightarrow \mathrm{CxCr}^{-1-}$ mice. ${ }^{*} p<0.05$. Scale bars: $A, 250 \mu \mathrm{m} ; \mathbf{D}, 2 \mu \mathrm{m}$.

ing (Fig. $6 B, D$ ), which is $\sim 4 \mathrm{~d}$ earlier than $\mathrm{Cxcr} 2^{+/-} \rightarrow \mathrm{Cxcr} 2^{+/+}$ mice. In summary, early increased local OPC proliferation and differentiation in $\mathrm{Cxcr} 2^{+/-} \rightarrow \mathrm{CxCr} 2^{-1-}$ mice may contribute to the enhanced myelin repair.

Blockade of CXCR2 or CXCR2 deficiency in CNS causes rapid and better remyelination in an in vitro model of demyelination/remyelination in lysolecithin-treated cerebellar slice cultures

$\mathrm{Cxcr} 2^{-1-}$ mice are valuable for evaluating the function of CXCR2, but it is crucial to perform complementary experiments using receptor blockade, given the developmental effects of genetic deletion of CXCR2. It was not feasible to administer blocking antibodies during the entire time course of remyelination during EAE or cuprizone intoxication because chronic administration of an antibody will cause unpredictable side effects in mice, including induction of neutralizing antibodies. Therefore, we modified an in vitro model of demyelination/remyelination in lysolecithin-treated cerebellar slice cultures (Birgbauer et al., 2004) for application in mice. To address the effects of blocking CXCR2 during demyelination, slices were incubated in culture to permit myelination, and analyzed by duallabel immunohistochemistry for myelin protein MBP (green) and neurofilament (red) detected in nerve fibers, with myelinated fibers appearing yellow in merged images (Fig. 7Ai,j). After $17 \mathrm{~h}$ of lysolecithin exposure, cerebellar slices were extensively demyelinated with abundant green myelin debris and numerous red demyelinated fibers (Fig. $7 A a-d)$. Equivalent demyelination was observed in slice preparations exposed to medium (data not shown), neutralizing anti-CXCR2 antibodies (Fig. 7Ab), and control rabbit IgG (Fig. $7 A a, B)(p>0.05)$. At this time point, robust demyelination was also observed in slices from littermate $C x c r 2^{+/+}$(Fig. 7Ac) and Cxcr2 $2^{-1-}$ mice (Fig. $7 A d)$. After $2 \mathrm{~d}$ of recovery, vigorous remyelination was detected in slices incubated with anti-CXCR2 antibodies (Fig. 7Af) and in those from $C x \mathrm{cr} 2^{-1-}$ mice (Fig. 7Ah), whereas control slice preparations remained significantly demyelinated (Fig. 7Ae,g;B) $(p<0.01)$. At the $2 \mathrm{~d}$ time point, remyelination in control slice cultures (Fig. 7Ae,g) was not significantly different from that observed after the overnight incubation with LPC (Fig. 7Aa,c;B) $(p>$ $0.05)$. By contrast, in cultures in which CXCR2 had been blocked or deleted, myelin integrity was equivalent to that observed in control 
A Control

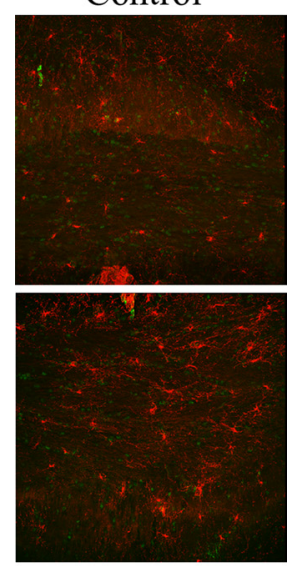

\section{B Control}
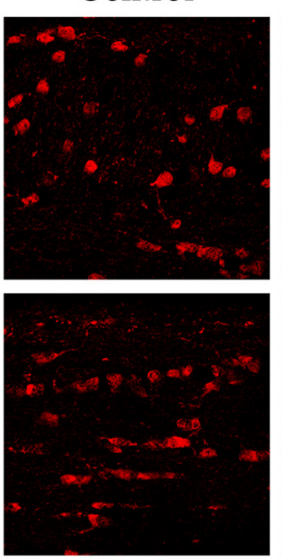

\section{C}

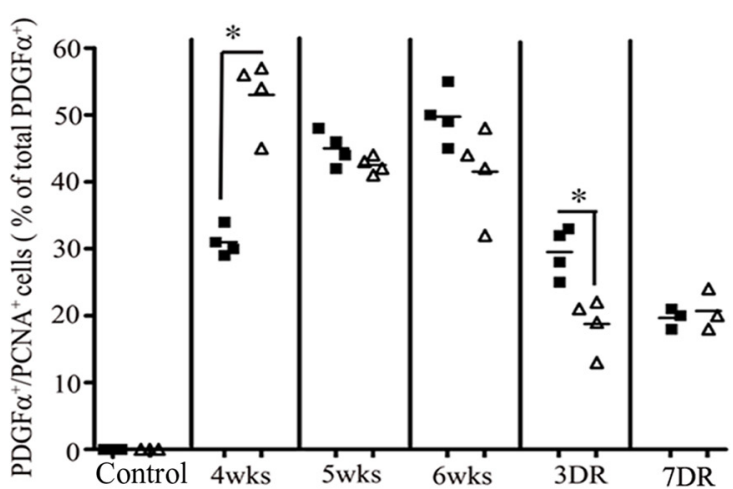

5 wks

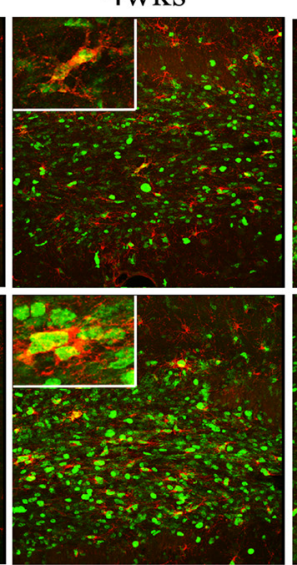

4 wks
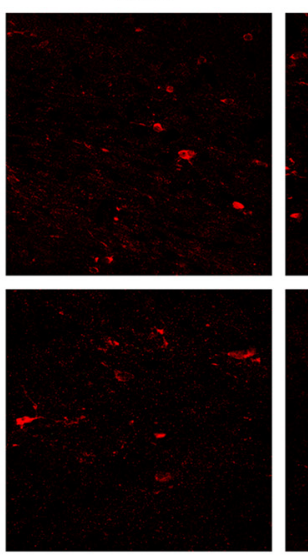

$6 \mathrm{wks}$

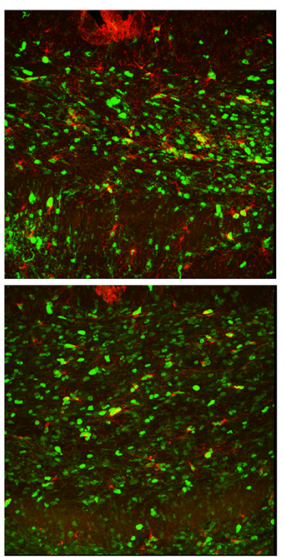

$5 w k s$
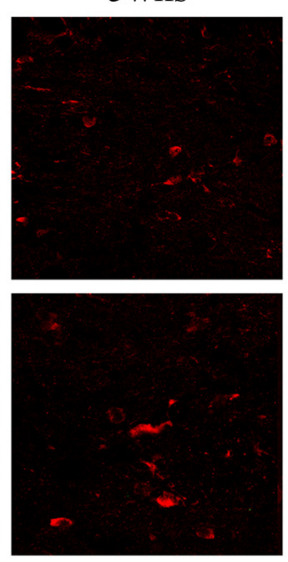

D
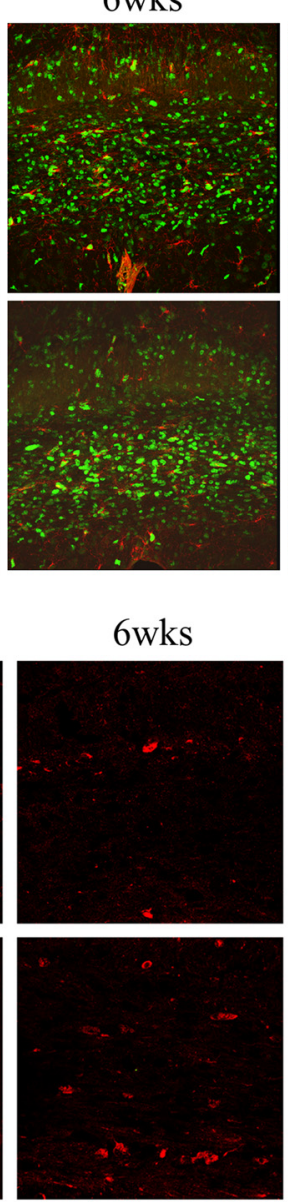

2500
$3 \mathrm{DR}$
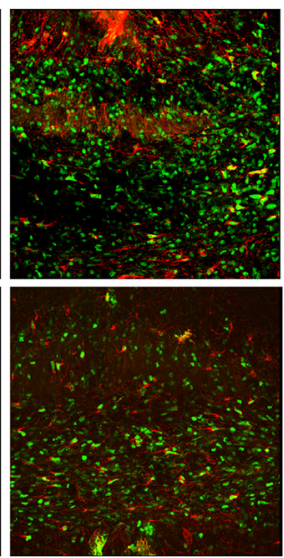

3DR
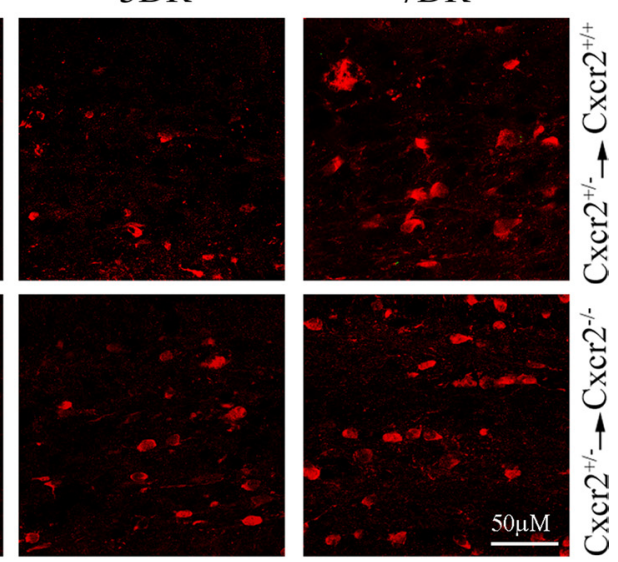

$\mathrm{Cxcr} 2^{++} \rightarrow \mathrm{Cxcr}^{+++}$

$\Delta \mathrm{Cxcr} 2^{++} \rightarrow \mathrm{Cxcr} 2-$
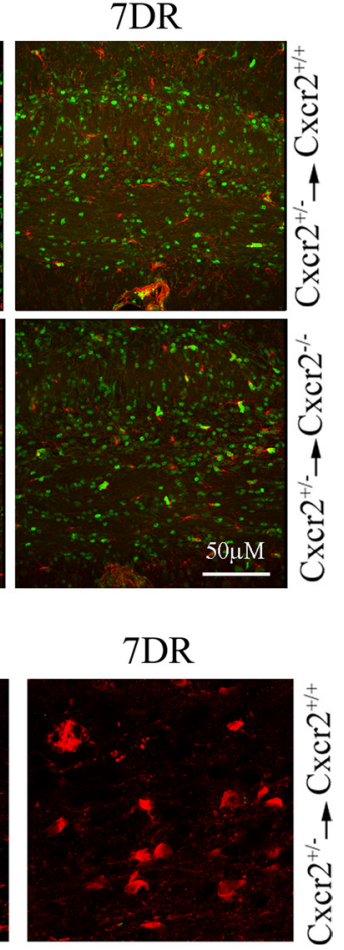

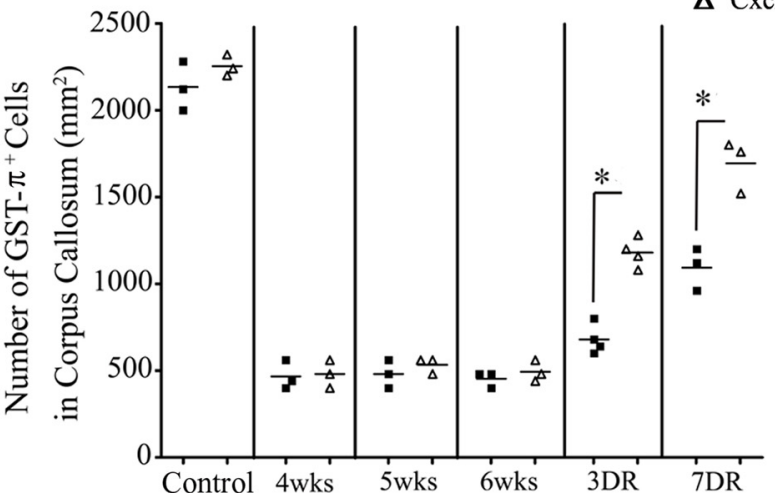

Figure 6. $\quad C x \mathrm{Cr} 2^{+/-} \rightarrow \mathrm{CxCr} 2^{-1-}$ mice generate OPCs after demyelination more quickly than $\mathrm{CxCr} 2^{+/-} \rightarrow \mathrm{CxCr} 2^{+/+}$mice, and OPCs divide more rapidly in demyelinated lesions. Cxcr2 ${ }^{+/-} \rightarrow \mathrm{CxCr}^{+/+}$ and $\mathrm{CxCr} 2^{+/-} \rightarrow \mathrm{CxCr} 2^{-1-}$ mice were fed cuprizone for 4, 5, or 6 weeks before killing. Additional mice were fed cuprizone for 6 weeks and recovered without cuprizone feeding for 3 or $7 \mathrm{~d}$ before killing. $A$, Costaining of PDGFR $\alpha$ and PCNA showed robust early proliferation of OPCs in $C \times C r 2^{+1-} \rightarrow C x C r 2^{-1-}$ mice (bottom) at 4 weeks of cuprizone treatment. $\boldsymbol{B}$, Immunofluorescence staining of GST- $\pi$ showed significantly larger numbers of GST- $\pi+$ oligodendrocytes at 3DR after 6 weeks cuprizone feeding in $C \times C r 2^{+/-} \rightarrow C x C r 2^{-1-}$ mice. C, Quantification of percentage of PDGFR $\alpha$ and PCNA + in total PDGFR $\alpha$ cells in corpus callosum during time course of cuprizone treatment. $D$, Quantification of numbers of of GST- $\pi$ in corpus callosum during time course of cuprizone treatment. ${ }^{*} p<0.05$. Scale bars: $A, B$ : $50 \mu m$.

cultures that had not been subjected to demyelination (Fig. 7Ai,j) $(p>0.05)$. These results were quantified and shown in Figure $7 B$. These results indicate that inactivation of CXCR2 by genetic deletion or by antibody-mediated blockade exerted similar effects and strongly enhanced the efficiency of remyelination in vitro.

\section{Discussion}

We evaluated CXCR2-deficent mice in two in vivo models and one in vitro model of demyelination/remyelination to demon- strate a selective and potent function of CXCR2 in accelerating remyelination. The findings from our study point to an important inhibitory role for CXCR2 signaling in remyelination during $\mathrm{EAE}$ and cuprizone-induced demyelination and in vitro LPCinduced demyelination of cerebellum slice culture. Kerstetter et al. (2009) reported that systemic injection of CXCR2 antagonist decreased the demyelinated lesions in the EAE model, although it remained unclear whether systemic injection of CXCR2 antagonist prevented demyelination or promoted remyelination (Carlson 
A
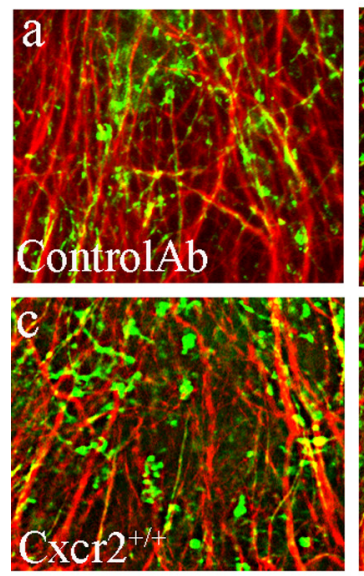

17 hours treatment
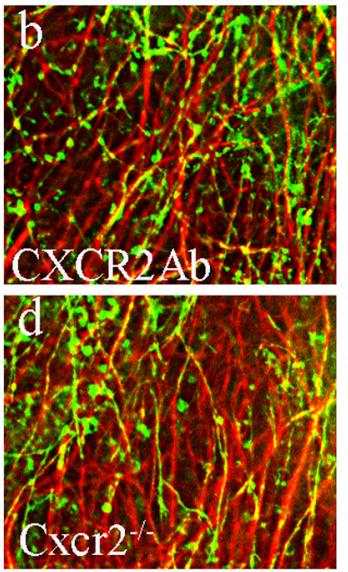

2 days recovery

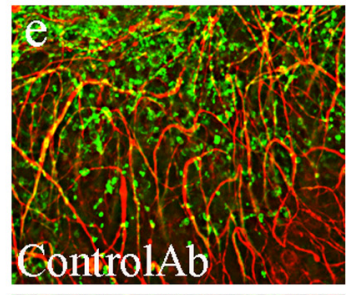

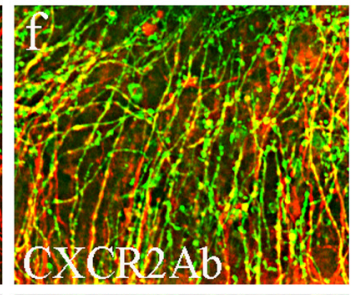
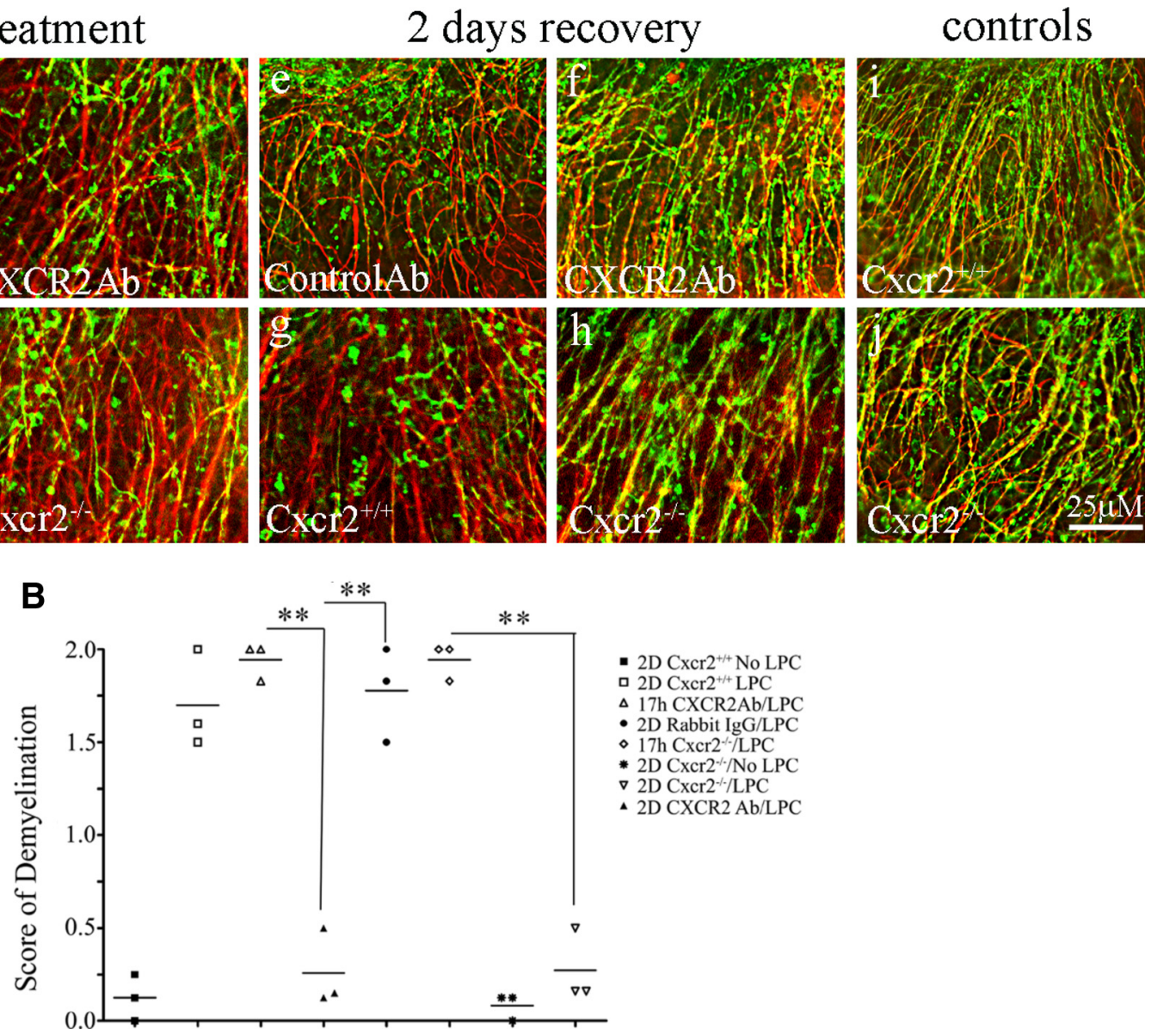

Figure 7. In vitro brain slice demyelination/remyelination assay shows accelerated remyelination in the absence of CXCR2 signaling. $A$, Cerebellar slice cultures from P10 CXcr2 ${ }^{+/+}$mice were dual labeled with myelin protein MBP (green) and neurofilament (red), and myelinated fibers appearing yellow in merged images. Lysolecithin-treated (17 h) slices were blocked with control antibodies (a) or CXCR2 antibodies $(\boldsymbol{b})$. Cerebellar slice cultures from $\mathrm{CXCr}^{+/+}(\boldsymbol{c})$ or $\mathrm{CXCr} 2^{-1-}(\boldsymbol{d})$ mice were similarly treated. At $17 \mathrm{~h}(\boldsymbol{a}-\boldsymbol{d})$, all slices are demyelinated, showing abundant red unmyelinated nerve fibers and scant yellow myelinated fibers. Two days after removing lysolecithin, poor remyelination is shown in slices treated with control antibodies (e) compared with neutralizing anti-CXCR2 antibodies $(\boldsymbol{f})$. There was also poor remyelination in $\mathrm{CxCr}^{+/+}(\boldsymbol{g})$ compared with $\mathrm{CxCr}^{-/-}(\boldsymbol{h})$ cerebellar slices. Non-demyelinated positive controls of $\mathrm{CxCr2}{ }^{+/+}$and $\mathrm{CxCr}^{-1-}$ were shown as $\boldsymbol{i}$ and $\boldsymbol{j}$, respectively, for myelination. Scale bar, $20 \mu \mathrm{m}$. B, Score of demyelination on lysolecuthin-treated slices. ${ }^{* *} p<0.01$.

et al., 2008; Liu et al., 2010). We addressed these distinctions by studying CXCR2-deficient mice. Our findings confirmed previous reports and extended these observations.

Remyelination is the best documented and most robust example of tissue repair in the human CNS and is unequivocally neuroprotective in MS (Kornek and Lassmann, 1999; Kornek et al., 2000). Approximately $40 \%$ of postmortem MS tissues demonstrate remyelination, which can occur both early and late in the course of MS (Patrikios et al., 2006). Factors that promote remyelination in vivo have been elusive.

Inhibiting CXCR2 for the treatment of inflammatory demyelination could simultaneously suppress inflammation and promote remyelination. The translational insights from using CXCR2-deficient mice were previously believed to be limited because of differences between humans and mice in the complement of receptors for ELR + CXC chemokines (Mestas and Hughes, 2004). However, recent identification of murine CXCR1 (Fan et al., 2007) relieved this concern, and our present results clearly show a nonredundant function for CXCR2 in remyelination. The roles of CXCR2 on hematopoietic cells were differentiated by generating and evaluating $\mathrm{Cxcr} 2^{+/-} \rightarrow \mathrm{Cxcr} 2^{-1-}$ and $\mathrm{CxCr} 2^{+1-} \rightarrow \mathrm{CxCr} 2^{+1+}$ radiation bone marrow chimeric mice. Transfer of CXCR2+ hematopoietic cells rendered recipient mice susceptible to EAE, regardless of whether the host genotype was $\mathrm{Cxcr} 2^{-1-}$ or $\mathrm{Cxcr2} 2^{+/+}$. In the SWXJ background, robust EAE-associated neurological impairment and histopathological changes were observed, despite CXCR2 haploinsufficiency of the donor marrow. Similarly, on the C57BL/6 background, $\mathrm{Cxcr}^{+/-} \rightarrow$ $\mathrm{CxCr} 2^{-1-}$ and $\mathrm{Cxcr} 2^{+/-} \rightarrow \mathrm{Cxcr}^{+/+}$mice demonstrated severe demyelination of the corpus callosum. Furthermore, comparison of $\mathrm{CxCr}^{+/-} \rightarrow \mathrm{CxCr}^{+/+}$mice with wild-type C57BL/6 mice demonstrated equivalent demyelination and repair after cuprizone feeding, showing that the radiation chimerism did not materially alter the sequence of tissue injury and restoration in this model (Liu et al., 2010). Therefore, our experimental strategy afforded an opportunity to evaluate the selective role of CXCR2 in myelin repair.

Despite finding an important role of CXCR2 in myelin repair in three different models, the detailed cellular requirements for remyelination of EAE and cuprizone-induced demyelinating lesions remain uncertain. Varied CNS cells, including OPCs, astrocytes, and neurons have been reported to express CXCR2, either in vitro or in vivo. Limited levels of CXCR2 mRNA impaired localization of the CXCR2 message by in situ hybridization, and available antibodies were found to be nonspecific since they equally detected immunoreactivity in the CNS of $\mathrm{Cxcr2}^{-/-}$and Cxcr2 $2^{+/+}$mice (Liu et al., 2010). By PCR on sorted oligodendrocytes, we found that oligodendrocytes highly express CXCR2 (data not shown). We favor the possibility that OPC expression of 
CXCR2 accounts for our results, as we observed enhanced OPC proliferation in mice lacking CNS CXCR2 in both EAE and cuprizone-induced demyelination. This result seemed initially counterintuitive, as CXCL1, a CXCR2 ligand, synergistically augmented proliferation of OPCs in vitro, in the presence of PDGF. In recent years, the neurorestorative properties of the acute lesion environment in rodent EAE and cuprizone-induced demyelination have been extensively studied (Franklin, 2002) and characterized as comprising IGF-1 (Komoly et al., 1992) as well as LIF, CNTF, PDGF-AA, TGF- $\beta 1$, and FGF- 2 . Factors that promote remyelination are made by resident astrocytes and microglia as well as infiltrating hematopoietic cells. Mixtures of growth factors enhance repair of cuprizone lesions on intracerebral microinjection (Kumar et al., 2007), and growth factor secretion by macrophages stimulates myelin production by brain-aggregate cultures (Diemel et al., 2004). Surprisingly, some inflammatory cytokines that govern lesion formation also promote repair of cuprizone-induced demyelination, demonstrating the intimate interrelationship between demyelination and remyelination, and the restorative properties of acute inflammatory lesions (Gao et al., 2000; Mason et al., 2001). We propose that OPCs from $\mathrm{CxCr} 2^{-1-}$ mice accumulated in the growth-promoting microenvironment of inflammatory demyelinating lesions with increased efficiency. As a corollary, we hypothesize that CXCR2-bearing OPCs were arrested at lesion edges, where CXCR2 ligands were preferentially expressed (Glabinski et al., 1997; Omari et al., 2006). These results indicate that the factors that orchestrate migration, proliferation, and differentiation during development of the oligodendrocyte lineage in the mammalian CNS do not enable efficient myelin repair in the models under study here and suggest that therapeutic intervention at this level may provide tangible benefits.

Together, CXCR2 is the first chemokine receptor shown to contribute robustly to both the inflammatory processes that cause demyelination and to the pathways that control remyelination (Liu et al., 2010). Our studies address the fundamental role of CXCR2 in demyelination and remyelination, and provide information needed for effective clinical trials of CXCR2 blockade in MS. Future studies will address how the presence of CXCR2 impairs remyelination and define CNS cell types whose expression of CXCR2 leads to inefficient remyelination.

\section{References}

Birgbauer E, Rao TS, Webb M (2004) Lysolecithin induces demyelination in vitro in a cerebellar slice culture system. J Neurosci Res 78:157-166.

Cacalano G, Lee J, Kikly K, Ryan AM, Pitts-Meek S, Hultgren B, Wood WI, Moore MW (1994) Neutrophil and B cell expansion in mice that lack the murine IL-8 receptor homolog. Science 265:682-684.

Carlson T, Kroenke M, Rao P, Lane TE, Segal B (2008) The Th17-ELR+ CXC chemokine pathway is essential for the development of central nervous system autoimmune disease. J Exp Med 205:811-823.

Devalaraja RM, Nanney LB, Du J, Qian Q, Yu Y, Devalaraja MN, Richmond A (2000) Delayed wound healing in CXCR2 knockout mice. J Invest Dermatol 115:234-244.

Diemel LT, Wolswijk G, Jackson SJ, Cuzner ML (2004) Remyelination of cytokine- or antibody-demyelinated CNS aggregate cultures is inhibited by macrophage supplementation. Glia 45:278-286.

Fan X, Patera AC, Pong-Kennedy A, Deno G, Gonsiorek W, Manfra DJ, Vassileva G, Zeng M, Jackson C, Sullivan L, Sharif-Rodriguez W, Opdenakker G, Van Damme J, Hedrick JA, Lundell D, Lira SA, Hipkin RW (2007) Murine CXCR1 is a functional receptor for GCP-2/CXCL6 and interleukin-8/CXCL8. J Biol Chem 282:11658-11666.
Franklin RJ (2002) Why does remyelination fail in multiple sclerosis? Nat Rev Neurosci 3:705-714.

Gao X, Gillig TA, Ye P, D’Ercole AJ, Matsushima GK, Popko B (2000) Interferon-gamma protects against cuprizone-induced demyelination. Mol Cell Neurosci 16:338-349.

Glabinski AR, Tani M, Strieter RM, Tuohy VK, Ransohoff RM (1997) Synchronous synthesis of alpha- and beta-chemokines by cells of diverse lineage in the central nervous system of mice with relapses of chronic experimental autoimmune encephalomyelitis. Am J Pathol 150:617-630.

Kerstetter AE, Padovani-Claudio DA, Bai L, Miller RH (2009) Inhibition of CXCR2 signaling promotes recovery in models of multiple sclerosis. Exp Neurol 220:44-56.

Komoly S, Hudson LD, Webster HD, Bondy CA (1992) Insulin-like growth factor I gene expression is induced in astrocytes during experimental demyelination. Proc Natl Acad Sci U S A 89:1894-1898.

Kornek B, Lassmann H (1999) Axonal pathology in multiple sclerosis. A historical note 139. Brain Pathol 9:651-656.

Kornek B, Storch MK, Weissert R, Wallstroem E, Stefferl A, Olsson T, Linington C, Schmidbauer M, Lassmann H (2000) Multiple sclerosis and chronic autoimmune encephalomyelitis: a comparative quantitative study of axonal injury in active, inactive, and remyelinated lesions. Am J Pathol 157:267-276.

Kumar S, Biancotti JC, Yamaguchi M, de Vellis J (2007) Combination of growth factors enhances remyelination in a cuprizone-induced demyelination mouse model. Neurochem Res 32:783-797.

Liu L, Graham GJ, Damodaran A, Hu T, Lira SA, Sasse M, Canasto-Chibuque C, Cook DN, Ransohoff RM (2006) Cutting edge: the silent chemokine receptor D6 is required for generating $\mathrm{T}$ cell responses that mediate experimental autoimmune encephalomyelitis. J Immunol 177:17-21.

Liu L, Belkadi A, Darnall L, Hu T, Drescher C, Cotleur AC, Padovani-Claudio D, He T, Choi K, Lane TE, Miller RH, Ransohoff RM (2010) CXCR2positive neutrophils are essential for cuprizone-induced demyelination: relevance to multiple sclerosis. Nat Neurosci 13:319-326.

Mason JL, Suzuki K, Chaplin DD, Matsushima GK (2001) Interleukin-1 $\beta$ promotes repair of the CNS. J Neurosci 21:7046-7052.

Matsushima GK, Morell P (2001) The neurotoxicant, cuprizone, as a model to study demyelination and remyelination in the central nervous system. Brain Pathol 11:107-116.

Menn B, Garcia-Verdugo JM, Yaschine C, Gonzalez-Perez O, Rowitch D, Alvarez-Buylla A (2006) Origin of oligodendrocytes in the subventricular zone of the adult brain. J Neurosci 26:7907-7918.

Mestas J, Hughes CC (2004) Of mice and not men: differences between mouse and human immunology. J Immunol 172:2731-2738.

Murtie JC, Zhou YX, Le TQ, Vana AC, Armstrong RC (2005) PDGF and FGF2 pathways regulate distinct oligodendrocyte lineage responses in experimental demyelination with spontaneous remyelination. Neurobiol Dis 19:171-182.

Nait-Oumesmar B, Decker L, Lachapelle F, Avellana-Adalid V, Bachelin C, Van Evercooren AB (1999) Progenitor cells of the adult mouse subventricular zone proliferate, migrate and differentiate into oligodendrocytes after demyelination. Eur J Neurosci 11:4357-4366.

Omari KM, John G, Lango R, Raine CS (2006) Role for CXCR2 and CXCL1 on glia in multiple sclerosis. Glia 53:24-31.

Padovani-Claudio DA, Liu L, Ransohoff RM, Miller RH (2006) Alterations in the oligodendrocyte lineage, myelin, and white matter in adult mice lacking the chemokine receptor CXCR2. Glia 54:471-483.

Patrikios P, Stadelmann C, Kutzelnigg A, Rauschka H, Schmidbauer M, Laursen H, Sorensen PS, Brück W, Lucchinetti C, Lassmann H (2006) Remyelination is extensive in a subset of multiple sclerosis patients. Brain 129:3165-3172.

Pedchenko TV, LeVine SM (1999) IL-6 deficiency causes enhanced pathology in Twitcher (globoid cell leukodystrophy) mice. Exp Neurol 158:459-468.

Tsai HH, Frost E, To V, Robinson S, ffrench-Constant C, Geertman R, Ransohoff RM, Miller RH (2002) The chemokine receptor CXCR2 controls positioning of oligodendrocyte precursors in developing spinal cord by arresting their migration. Cell 110:373-383.

Yu M, Nishiyama A, Trapp BD, Tuohy VK (1996) Interferon-beta inhibits progression of relapsing-remitting experimental autoimmune encephalomyelitis. J Neuroimmunol 64:91-100. 